\title{
Novel microsatellites for Cypseloides fumigatus, cross-amplifiable in Streptoprocne zonaris
}

\author{
Renata Neves Biancalana ${ }^{1,2,4}$, Fabio Raposo do Amaral $^{3} \&$ Cibele Biondo $^{1}$ \\ ${ }^{1}$ Centro de Ciências Naturais e Humanas, Programa de Pós-graduação em Evolução e Diversidade, Universidade Federal do ABC. São Bernardo do \\ Campo, SP, Brazil. \\ 2 Current address: Programa de Pós-graduação em Zoologia, Universidade Federal do Pará/Museu Paraense Emílio Goeldi, Belém, PA, Brazil. \\ 3 Departamento de Ecologia e Biologia Evolutiva, Universidade Federal de São Paulo. Diadema, SP, Brazil. \\ 4 Corresponding author: renata.biancalana@gmail.com
}

Received on 26 February 2019. Accepted on 26 July 2019.

\begin{abstract}
Based on microsatellite prospection, we isolated and characterized 21 microsatellite markers for the Sooty Swift (Cypseloides fumigatus) and tested the cross-amplification in the White-collared Swift (Streptoprocne zonaris). Both species are New World species included in the Apodidae family. From these 21, only 13 loci were polymorphic in the Sooty Swift, and their levels of polymorphism were surprisingly low compared to related species. Cross-amplification in the White-collared Swift was successful for 11 loci of the 13 polymorphic found for the Sooty Swift, but seven were monomorphic and four were biallelic. The microsatellites described here could be useful in future genetic population studies for Sooty Swifts and related species.
\end{abstract}

KEY-WORDS: Cypseloidinae, Sooty Swift, Ultraconserved elements (UCEs), White-collared Swifts.

Sooty Swifts, Cypseloides fumigatus, and White-collared Swifts, Streptoprocne zonaris, are New World apodid species. Whereas the White-collared Swift has a wide distribution, ranging from southern USA to southwestern Argentina, the Sooty Swift ranges from Argentina to Bolivia, Brazil and Paraguay (Chantler 1999). Both species present highly aerial behavior and are frequently seeing foraging and nesting together (Marín \& Stiles 1992, Pearman et al. 2010, Biancalana et al. 2012, Biancalana $2014 \& 2015)$. They nest in colonies, usually next to waterfalls and wet caves. Like other swift species they are philopatric, returning to use the same nest site over several years (Marín \& Stiles 1992, Collins \& Foerster 1995, Biancalana, pers. obs.). Here, we describe and characterize 13 novel polymorphic microsatellites for the Sooty Swift. In addition, we cross-amplified 11 of the 13 loci in the White-collared Swift from which seven were monomorphic and four were biallelic.

Microsatellite prospection was based on off-target sequences obtained through sequence capture and nextgeneration sequencing of Ultraconserved Elements (UCEs), as described in Amaral et al. (2015). Genomic DNA was obtained from a muscle sample from a Sooty Swift individual deposited at the Laboratório de Genética e Evolução Molecular de Aves (Universidade de Sáo Paulo USP, Brazil - LGEMA \#11411), collected at Ortigueira, Paraná state $\left(24^{\circ} 12^{\prime} \mathrm{S} ; 50^{\circ} 55^{\prime} \mathrm{W}\right)$ using the Qiagen DNeasy kit (Valencia, CA) with an RNAse treatment. Sequencing was performed at Rapid Genomics (Gainesville, FL, USA). The contigs obtained were screened for perfect di-, tri-, tetra-, penta-, and hexa-nucleotide with at least five repeats using QDD (Meglécz et al. 2010). QDD and Primer3 (Koressaar \& Remm 2007, Untergasser et al. 2012) were used to design primers with default parameters and minimum fragment length of $100 \mathrm{bp}$. Each forward primer was designed with a M13 sequence (CACGACGTTGTAAAACGAC) added to its 5' end in order to pair with a third fluorescently labeled primer, according to the universal labeling method described by Boutin-Ganache et al. (2001).

For the characterization of the prospected microsatellites, 34 samples of Sooty Swifts were collected: 19 at Intervales State Park (ISP, Ribeirão Grande, São Paulo state, Brazil) and 15 at Sussuapara Canyon (SC, Ponte Alta do Tocantins, Tocantins state, Brazil). Both sites are known to have nests of the species and are monitored since 2010 (SC) and 2012 (ISP). To check the cross-amplification for White-collared Swifts, 10 adult samples were collected at ISP. Adults were mist netted and nestlings were captured in their nests and returned after sampling. Blood samples were collected from the brachial vein using microcapillary tubes and stored in absolute ethanol under room temperature. Genomic DNA was extracted from whole blood with a salt protocol adapted 
from Aljanabi \& Martinez (1997).

PCRs were carried out in volumes of $12 \mu \mathrm{l}$ containing $1.5 \mu \mathrm{l}$ of extracted DNA $(30-50 \mathrm{ng} / \mu \mathrm{l}), 0.2 \mathrm{mM}$ of dNTPs, $1 \times$ PCR buffer, 3 pmol of the reverse primer, 1 pmol of forward primer, 2 pmol of FAM/HEX M13 primer, $2.5 \mathrm{mM}$ of $\mathrm{MgCl}_{2}$ and $0.5 \mathrm{U}$ of Taq Polymerase (Sinapse, Inc.). Thermocycling conditions consisted of $95^{\circ}(5 \mathrm{~min}), 35$ cycles at $94^{\circ} \mathrm{C}(30 \mathrm{~s}), \mathrm{T}_{\mathrm{A}}^{\circ} \mathrm{C}(30 \mathrm{~s})$, $72^{\circ} \mathrm{C}(30 \mathrm{~s})$ with a final extension at $72^{\circ} \mathrm{C}(10 \mathrm{~min})$. The optimal annealing temperature for each primer pair was determined using a temperature gradient cycle from 56 to $64{ }^{\circ} \mathrm{C}$ with a $2{ }^{\circ} \mathrm{C}$ difference between steps. PCR products were visualized on a $1.5 \%$ agarose gel using a $100 \mathrm{bp}$ ladder. Successful PCR products were genotyped on a ABI 3730 (Applied Biosystems) automated sequencer and analyzed with GeneMarker 2.7.0 (Softgenetics).

We used GenAlEx 6.5 (Peakall \& Smouse 2012) to estimate the number of alleles, and expected and observed heterozygosities. GENEPOP 4.2 (Raymond \& Rousset 1995, Rousset 2008) was used to search for deviations from Hardy-Weinberg and linkage equilibrium. Benjamini \& Yekutieli (2001) correction was applied to adjust the critical values for multiple comparisons. The search for null alleles and the estimation of their frequencies was done using MICRO-CHECKER 2.2.3 (van Oosterhout et al. 2004).

A total of 423 microsatellites were prospected for the Sooty Swift. From these, 138 (32.6\%) were linked to UCEs regions and were discarded from primer design as they may be under purifying selection (Harvey et al. 2016) and are possibly monomorphic. From the remaining 285 microsatellites, we designed primers for 21 perfect loci (Table 1). Most were dinucleotides (81.0\%), followed by trinucleotides (14.3\%) and one pentanucleotide (4.8\%). From the 21 loci tested in the 34 samples of Sooty Swifts, 16 were successfully amplified in Sooty Swifts (Table 1). Although the loci Cyps23 and Cyps34 successfully amplified, they did not produce consistent genotypes due to an excess of stutter bands. Thirteen loci were polymorphic with the number of alleles ranging from 2 to 8 (mean \pm SD: $3.3 \pm 0.43$, Table 1$)$. Observed heterozygosities ranged from 0.03 to 0.56 (mean $\mathrm{Ho} \pm$ SD: $0.16 \pm 0.05$ ) and expected heterozygosities from 0.03 to 0.67 (mean $\mathrm{He} \pm \mathrm{SD}: 0.25 \pm 0.06$, Table 1 ). These heterozygosities were low when compared to that of phylogenetically close species, though the microsatellites used in the reference literature where not the same as those designed and tested in this study (Lance et al. 2009, González et al. 2010, Oyler-McCance et al. 2011, Gutiérrez-Rodriguez et al. 2013, Sanvicente et al. 2016; Table 2). Several attempts of amplification using two hummingbird microsatellites developed in other studies, Acya3-3 and Hxan07 (Gutiérrez-Rodriguez et al. 2013, Sanvicente et al. 2016), were done by RNB, with different settings of temperature and thermocycling conditions, but resulted in no amplifications for Sooty and Whitecollared Swifts.

The test on Hardy-Weinberg equilibrium (HWE) for each locus revealed deviations in 5 loci after Benjamini \& Yekutieli (2001) correction (Cyps8, Cyps14, Cyps26, Cyps33, and Cyps35 - Table 1). The following loci had evidence of null alleles (with their respective frequencies): Cyps8 (0.237), Cyps14 (0.281), Cyps24 (0.156), Cyps26 (0.310), and Cyps33 (0.279). Among 91 paired loci, four cases of linkage disequilibrium were detected for the loci Cyps8 and Cyps12, Cyps12 and Cyps25, Cyps 14 and Cyps26, and Cyps24 and Cyps35 $[P<0.01$ after Benjamini \& Yekutieli (2001) correction]. The deviations to HWE might be caused by the presence of null alleles in some loci (Cyps8, Cyps14, Cyps26, Cyps33 and Cyps36), or due to population substructure, since samples were collected in different localities. The cross-amplification of the prospected loci in Whitecollared Swifts was successful for 11 of them. However, the loci were either monomorphic or biallelic (Table 1). Locus Cyps9, that did not amplify in Sooty Swifts, was successfully amplified for White-collared Swifts.

The low polymorphism found in Sooty Swift microsatellites may result from many factors, ranging from loci linked to conserved regions to ecological and historical factors. Milot et al. (2007) suggested, for example, that some life history traits associated with demographic patterns may result in a small effective population size, that in long periods of time can result in loss of genetic diversity. This means that not only bottlenecks might be the main cause for low genetic variability in birds (Amos \& Harwood 1998). Because Sooty Swifts usually establishes small populations (ranging from two to ten individuals in general), exhibits philopatry, presents a long breeding period and raises just one chick per year (Biancalana et al. 2012, Biancalana 2015), the population might be suffering from inbreeding and/or might naturally have low genetic variability. Alternatively, population size variation due to historical factors - as climate change in the past - could also explain low genetic variation. Additional studies will be important to test alternative scenarios related to the low nuclear variation found here. The microsatellites described here will be useful to explore both ecology and evolution of Sooty Swift and closely related species.

\section{ACKNOWLEDGEMENTS}

We are grateful to R.G. Lima for collecting the specimen used to prospect the microsatellites, and C.Y. Miyaki for loaning the tissue sample under her care at LGEMA (Laboratório de Genética e Evolução Molecular de Aves, 
Table 1. Characterization of 21 microsatellite loci isolated from Cypseloides fumigatus and their cross-amplification in Streptoprocne zonaris

\begin{tabular}{|c|c|c|c|c|c|c|c|c|c|c|c|c|}
\hline \multirow{2}{*}{ Locus } & \multirow{2}{*}{ Primer sequence $\left(5^{\prime}-3^{\prime}\right)$} & \multirow{2}{*}{$\begin{array}{c}\text { GenBank } \\
\text { accession } \\
\text { No. }\end{array}$} & \multirow{2}{*}{$\begin{array}{c}\text { Repeat } \\
\text { motif }\end{array}$} & \multicolumn{6}{|c|}{ Cypseloides fumigatus } & \multicolumn{3}{|c|}{$\begin{array}{c}\text { Streptoprocne } \\
\text { zonaris }\end{array}$} \\
\hline & & & & $\begin{array}{c}T_{\mathrm{a}} \\
\left({ }^{\circ} \mathbf{C}\right)\end{array}$ & $n_{a}$ & $\begin{array}{l}\text { Size range } \\
\text { (bp) }\end{array}$ & $\mathbf{H}_{\mathrm{o}}$ & $\mathbf{H}_{\mathrm{e}}$ & $P$-value & $\begin{array}{c}T_{\mathrm{a}} \\
\left({ }^{\circ} \mathrm{C}\right)\end{array}$ & $n_{a}$ & $\begin{array}{l}\text { Size range } \\
\text { (bp) }\end{array}$ \\
\hline \multirow[t]{2}{*}{ Cyps3 } & F: TGCCCAGGGCTCTAAAAGTA & MF568530 & $(\mathrm{AG})_{5}$ & 58 & 2 & $282-286$ & 0.032 & 0.032 & - & NSA & - & - \\
\hline & R: GCCACAATAGCAGCACAGAA & & & & & & & & & & & \\
\hline \multirow[t]{2}{*}{ Cyps8 } & F: GGCTTGACCATGAGAACCAT & MF568531 & $(\mathrm{CT})_{5}$ & 60 & 3 & $107-129$ & 0.029 & 0.189 & $0.0001^{*}$ & 60 & 1 & 121 \\
\hline & R: CAACATTGTCCCTGTGATCG & & & & & & & & & & & \\
\hline \multirow[t]{2}{*}{ Cyps9 } & F: GGTGATGTCATTTCСССТCT & MF579401 & $(\mathrm{AGC})_{5}$ & NSA & - & - & - & - & - & 52 & 2 & $76-97$ \\
\hline & R: TTAGAAAGTGCCAGAGAAGTATCA & & & & & & & & & & & \\
\hline \multirow[t]{2}{*}{ Cyps12 } & F: GAGGCTGCAGAAAAGCTGTC & MF579402 & $(\mathrm{AG})_{5}$ & 58 & 3 & $179-193$ & 0.118 & 0.112 & 1 & 58 & 2 & $179-181$ \\
\hline & R: ACCCTGCTGTTCAAGGTGTT & & & & & & & & & & & \\
\hline \multirow[t]{2}{*}{ Cyps 14} & F: AGGGGTGGAGATCAGACTCA & MF579403 & $(\mathrm{AC})_{5}$ & 58 & 3 & $128-142$ & 0.125 & 0.420 & $0.0000^{*}$ & NSA & - & - \\
\hline & R: AGTCССТTTCTTCСССТCTG & & & & & & & & & & & \\
\hline \multirow[t]{2}{*}{ Cyps20 } & F: CATGGCTTCCTCCTTTCTGT & MF579404 & $(\mathrm{TG})_{5}$ & 58 & 3 & $102-130$ & 0.212 & 0.195 & 1 & 58 & 2 & $109-131$ \\
\hline & R: TGGGATGACTTGTTTCTCCTG & & & & & & & & & & & \\
\hline \multirow[t]{2}{*}{ Cyps22 } & F: CCCTCGTGACCATTTTCTGT & MF579405 & $(\mathrm{CT})_{5}$ & 58 & 2 & $203-207$ & 0.065 & 0.062 & 1 & 58 & 1 & 203 \\
\hline & R: GGTCACACAGAGGGGAAAAA & & & & & & & & & & & \\
\hline \multirow[t]{2}{*}{ Cyps23 } & F: CGGCTAAACTGCAAGGAAAA & MF579406 & $(\mathrm{GA})_{9}$ & 62 & - & - & - & - & - & 62 & - & - \\
\hline & R: CCTATGGGCTGCTCTGCTAC & & & & & & & & & & & \\
\hline \multirow[t]{2}{*}{ Cyps 24} & F: GACAGAAGCCTTTCCAGTGC & MF579407 & $(\mathrm{CA})_{5}$ & 64 & 4 & $200-208$ & 0.138 & 0.219 & 0.0239 & 64 & - & - \\
\hline & R: TGAGACCGGAGCTGTCTTTT & & & & & & & & & & & \\
\hline \multirow[t]{2}{*}{ Cyps 25} & F: CATCTCCCAGGTGTTTTCGT & MF579408 & $(\mathrm{AG})_{5}$ & 56 & 3 & $232-240$ & 0.067 & 0.065 & 1 & 56 & 2 & $228-232$ \\
\hline & R: AGTTGGGAAAAGAGCACAGC & & & & & & & & & & & \\
\hline \multirow[t]{2}{*}{ Сурs26 } & F: AGGAAAGAGCCCTCTGCAAT & MF579409 & $(\mathrm{TC})_{5}$ & 56 & 8 & $129-173$ & 0.200 & 0.610 & $0.0000^{*}$ & 56 & 1 & 149 \\
\hline & R: TGGGGAGCAGAAGTAGCTGT & & & & & & & & & & & \\
\hline \multirow[t]{2}{*}{ Cyps27 } & F: AAATGCTGGCAAAGGTCTTG & MF579410 & $(\mathrm{TG})_{5}$ & NSA & - & - & - & - & - & NSA & - & - \\
\hline & R: CCGTGTCCCTCACTCAGACT & & & & & & & & & & & \\
\hline \multirow[t]{2}{*}{ Cyps28 } & F: CAAACATCTGCACCССТTTT & MF579411 & $(\mathrm{GT})_{5}$ & 56 & 1 & 153 & - & - & - & 60 & 1 & 151 \\
\hline & R: CTGACACTCGGCACAGACAT & & & & & & & & & & & \\
\hline \multirow[t]{2}{*}{ Cyps30 } & F: GATTCAATGGAGTAAATGGGTAG & MF579412 & $(\mathrm{AAT})_{5}$ & 56 & 4 & $229-241$ & 0.071 & 0.103 & $0.0506^{*}$ & NSA & - & - \\
\hline & R: TGAAGGTCTAAAGCCTCCTCAG & & & & & & & & & & & \\
\hline \multirow[t]{2}{*}{ Cyps31 } & F: GCGATAATGGGTGGACACTT & MF579413 & $(\mathrm{TA})_{5}$ & NSA & - & - & - & - & - & NSA & - & - \\
\hline & R: GATCGCTCCTCCAAAATGTG & & & & & & & & & & & \\
\hline Cyps32 & F: GGAGTAGGAGCAGCACAAGC & MF579414 & $(\mathrm{GAG})_{5}$ & NSA & - & - & - & - & - & NSA & - & - \\
\hline & R: ATCAGACACTGAGGCCATCC & & & & & & & & & & & \\
\hline Cyps33 & F: TATTTCTTTTGGGGGTGCTG & MF579415 & $(\mathrm{TG})_{5}$ & 62 & 3 & $148-156$ & 0.033 & 0.235 & $0.0000^{*}$ & NSA & - & - \\
\hline & R: CACACTGTCAACССАССТTG & & & & & & & & & & & \\
\hline Cyps34 & F: GTCTGGGAACTGTCCCCTTT & MF579416 & $(\mathrm{TG})_{6}$ & 60 & - & - & - & - & - & 60 & 1 & 161 \\
\hline & R: AGACTGGGACCCAAGGATG & & & & & & & & & & & \\
\hline Cyps35 & F: GGCCAGTATTAATGAAGCAGATG & MF579417 & $(\mathrm{CT})_{9}$ & 58 & 4 & $149-155$ & 0.560 & 0.671 & $0.0059^{*}$ & 58 & 1 & 149 \\
\hline & R: GCCTGTGGGGCATTAAAGAT & & & & & & & & & & & \\
\hline Cyps36 & F: GGGATGCCTACAGTGAAAGG & MF579418 & $(\mathrm{GA})_{5}$ & 58 & 3 & $152-156$ & 0.533 & 0.638 & 0.3839 & 58 & 1 & 152 \\
\hline & R: TTCTTGCCAGCAACTTTGAA & & & & & & & & & & & \\
\hline Cyps37 & F: TGTATTAAAGCAACCTTTCAGTGC & MF579419 & $(\text { AAAAC })_{8}$ & NSA & - & - & - & - & - & NSA & - & - \\
\hline & R: CCAGCCACACCTTTTACTGC & & & & & & & & & & & \\
\hline
\end{tabular}

Forward (F) and reverse (R) primer sequence, $T_{\mathrm{a}}$ annealing temperature, NSA no successful amplification, $n_{a}$ number of alleles, observed $\left(H_{\mathrm{o}}\right)$ and expected $\left(H_{\mathrm{e}}\right)$ heterozygosity, $P$-value of the Hardy-Weinberg equilibrium test. ${ }^{*}$ Significant values, considering Benjamini \& Yekutieli $(2001)$ correction $(P<0.015)$. 
Table 2. Comparison of the number of alleles ranges, mean observed $\left(\mathrm{H}_{\mathrm{o}}\right)$ and expected $\left(\mathrm{H}_{\mathrm{e}}\right)$ heterozygosities between microsatellite loci developed for Cypseloides fumigatus and that developed for some hummingbird species.

\begin{tabular}{llccccl}
\hline Family & Species & $\begin{array}{c}\text { Number } \\
\text { of loci }\end{array}$ & $\boldsymbol{n}_{\boldsymbol{a}}$ & $\mathbf{H}_{\mathbf{o}}$ & $\mathbf{H}_{\mathbf{e}}$ & Reference \\
\hline Apodidae & Cypseloides fumigatus & 13 & $2-8$ & 0.156 & 0.254 & This study \\
Trochilidae & Hylocharis xantusii & 16 & $3-10$ & 0.68 & 0.7 & Sanvicente et al. 2016 \\
Trochilidae & Hylocharis leucotis & 14 & $2-8$ & 0.35 & 0.41 & Sanvicente et al. 2016 \\
Trochilidae & Calypte costae & 14 & $2-6$ & 0.49 & 0.53 & Sanvicente et al. 2016 \\
Trochilidae & Campylopterus curvipennis & 10 & $2-13$ & 0.529 & 0.610 & González et al. 2010 \\
Trochilidae & Amazilia cyanocephala & 10 & $2-13$ & - & - & Gutiérrez-Rodriguez et al. 2013 \\
Trochilidae & Selasphorus platycercus & 10 & $2-16$ & - & - & Oyler-McCance et al. 2011 \\
Trochilidae & Trochilus spp. & 15 & $2-10$ & - & - & Lance et al. 2009 \\
\hline
\end{tabular}

USP). This work was funded by FAPESP (grants 2011/50143-7, 2011/23155-4 and 013/50297-0), NASA and National Science Foundation (grant DOB 1343578), CNPq (grant 479760/2012-8), and Association of Field Ornithologists (Alexander F. Skutch Award). We are also grateful to CNPq Process 312697/2018-0. This study was funded in part by the Coordenação de Aperfeiçoamento de Pessoal de Nivel Superior - Brasil (CAPES) - Finance Code 001.

\section{REFERENCES}

Aljanabi S.M. \& Martinez I. 1997. Universal and rapid salt-extraction of high quality genomic DNA for PCR-based techniques. Nucleic Acids Research 25: 4692-4693.

Amaral F.R., Neves L.G., Resende-Jr. M.F.R., Mobili F., Miyaki C.Y., Pellegrino K.C.M. \& Biondo C. 2015. Ultraconserved elements sequencing as a low-cost source of complete mitochondrial genomes and microsatellite markers in non-model amniotes. PLoS One 10: e0138446.

Amos W. \& Harwood J. 1998. Factors affecting levels of genetic diversity in natural populations. Philosophical Transactions of the Royal Society of London B: Biological Sciences 353: 177-186.

Benjamini Y. \& Yekutieli D. 2001. The control of the false discovery rate in multiple testing under dependency. Annals of Statistics 29: $1165-1188$.

Biancalana R.N. 2014. Breeding biology of the White-collared Swift Streptoprocne zonaris in southeastern Brazil. Revista Brasileira de Ornitologia 22: 341-346.

Biancalana R.N. 2015. Breeding biology of the Sooty Swift (Cypseloides fumigatus) in São Paulo, Brazil. Wilson Journal of Ornithology 127 : 402-410.

Biancalana R.N., Nogueira W., Bessa R., Pioli D., Albano C. \& Lees A.C. 2012. Range extensions and breeding biology observations of the Sooty Swift (Cypseloides fumigatus) in the states of Bahia, Goiás, Minas Gerais and Tocantins. Revista Brasileira de Ornitologia 20: 87-92.

Boutin-Ganache I., Raposo M., Raymond M. \& Deschepper C.F. 2001. M13-tailed primers improve the readability and usability of microsatellite analyses performed with two different allele-sizing methods. Biotechniques 31: 24-27.

Chantler P. 1999. Family Apodidae (swifts). In: del Hoyo J., Elliott A.
\& Sargatal J. (eds.). Handbook of the birds of the world, v. 5 (barnowls to hummingbirds). Barcelona: Lynx Editions.

Collins C.T. \& Foerster K.S. 1995. Nest site fidelity and adult longevity in the Black Swift (Cypseloides niger). North American Bander 20: 11-14.

González C., Gutiérrez-Rodríguez C. \& Ornelas J.F. 2010. Isolation, characterization and cross species amplification of microsatellite loci in a lek-breeding hummingbird (Campylopterus curvipennis, Tochilidae). Molecular Ecology Resources 10: 232-236.

Gutiérrez-Rodríguez C., Covarrubias S., González C. \& Ornelas J.F. 2013. Isolation, characterization and cross amplification of microsatellite loci in the azure-crowned hummingbird (Amazilia cyanocephala, Trochilidae). Permanent Genetic Resources added to Molecular Ecology Resources Database 01 February 2013-31 March 2013. Molecular Ecology Resources Primer Development Consortium. Molecular Ecology Resources 13: 760-762.

Harvey M.G., Smith B.T., Glenn T.C. Faircloth B.C. \& Brumfield R.T. 2016. Sequence capture versus restriction site associated DNA sequencing for shallow systematics. Systematic Biology 65: 910-924.

Koressaar T. \& Remm M. 2007. Enhancements and modifications of primer design program Primer3. Bioinformatics 23: 1289-1291.

Lance S.L., Hagen C., Glenn T.C., Brumfield R.T., Stryjewski K.F. \& Graves G.R. 2009. Fifteen polymorphic microsatellite loci from Jamaican streamertail hummingbirds (Trochilus). Conservation Genetics 10: 1195-1198.

Marín M. \& Stiles F.G. 1992. On the biology of five species of swifts (Apodidae, Cypseloidinae) in Costa Rica. Proceedings of the Western Foundation of Vertebrate Zoology 4: 287-351.

Meglécz E., Costedoat C., Dubut V., Gilles A., Malausa T., Pech N. \& Martin J.F. 2010. QDD: a user-friendly program to select microsatellite markers and design primers from large sequencing projects. Bioinformatics 26: 403-404.

Milot E., Weimerskirch H., Duchesne P. \& Bernatchez L. 2007. Surviving with low genetic diversity: the case of albatrosses. Proceedings of the Royal Society of London B: Biological Sciences 274: 779-787.

Oyler-McCance S.J., Fike J.A., Talley-Farnham T., Engelman T. \& Engelman F. 2011. Characterization of ten microsatellite loci in the Broad-tailed Hummingbird (Selasphorus platycercus). Conservation Genetics Resources 3: 351-353.

Peakall R. \& Smouse P.E. 2012. GenAlEx 6.5: genetic analysis in Excel. Population genetic software for teaching and research-an update. Bioinformatics 28: 2537-2539.

Pearman M., Areta J.I., Roesler I. \& Bodrati A. 2010. Confirmation of the Sooty Swift (Cypseloides fumigatus) in Argentina with notes 
on its nest placement, seasonality, and distribution. Ornitologia Neotropical 21: 351-359.

Raymond M. \& Rousset F. 1995. GENEPOP (Version 1.2): population genetics software for exact tests and ecumenicism. Journal of Heredity 86: 248-249.

Rousset F. 2008. Genepop'007: a complete reimplementation of the Genepop software for Windows and Linux. Molecular Ecology Resources 8: 103-106.

Sanvicente C.G.-R., Rodríguez-Estrella R., Lozano-Garza O.A. \& García-De-Léon F.J. 2016. Genetic diversity of the endemic Xantus' Hummingbird using 16 novel polymorphic microsatellite loci, and their cross amplification between six related species. Open Journal of Genetics 6: 19-27.

Untergasser A., Cutcutache I., Koressaar T., Ye J., Faircloth B.C., Remm M. \& Rozen S.G. 2012. Primer3 - new capabilities and interfaces. Nucleic Acids Research 40: e115.

Van Oosterhout C., Hutchinson W.F., Wills D.P.M. \& Shipley P. 2004. Micro-Checker: software for identifying and correcting genotyping errors in microsatellite data. Molecular Ecology Notes 4: 535-538.

Associate Editor: Gustavo S. Cabanne. 